\title{
APPLICATION OF PUP1 MARKERS FOR IDENTIFICATION OF RICE (ORYZA SATIVA L.) CULTIVARS WITH TOLERANCE TO PHOSPHORUS DEFICIENCY
}

\author{
S. VELLAIKUMAR \& P. MALARVIZHI \\ Department of Soil Science and Agricultural Chemistry, Tamil Nadu Agricultural University,
}

Coimbatore, Tamil Nadu, India

\begin{abstract}
Phosphorus deficiency (PD) often exists in soils that severely limit rice growth and production due to fixation in soils with high free ferric oxides and aluminum in the clay fraction. It is a widespread problem and limits access of plants to Phosphorus even if it is present in the soil. P-efficient varieties should play a major role in increasing rice yield. Therefore in this study, a set of 120 rice genotypes (composed of upland cultivars and landraces) were grown in low $P$ soils with three different $P$ fertilizer dose inputs $\left(P_{0}, P_{25}\right.$ and $\left.P_{50} \mathrm{kgha}^{-1} P\right)$ to compare $P$ uptake efficiency. Results showed that, among the 120 genotypes, fifteen genotypes (12.5\%) which produced high grain yield were further screened for probable presence of Pup1 gene by PCR amplification by two Pup1 associated insertion and deletion (InDel) markers viz, Pup1-K46 and Pup1-K52. Among the fifteen genotypes PCR screening confirmed the presence of Pup1 gene in more than $90 \%$ of the genotypes. In summary, the identified genotypes may serve as sources of PD tolerance that would be useful in future rice breeding programmes.

KEYWORDS: Rice, Genotypic Variation, Phosphorus Deficiency (PD) \& Marker Assisted Selection (MAS)
\end{abstract}

Received: Jul 06, 2017; Accepted: Jul 31, 2017; Published: Aug 12, 2017; Paper Id.: IJASRAUG201794

\section{INTRODUCTION}

Rice (Oryza sativa L.) is the most important staple food for almost more than half of the world population and is grown on over 150 million ha worldwide. Rice provides a source of carbohydrate and it provides $21 \%$ of energy and $15 \%$ of the protein requirements of human beings. Although rice farming is the major livelihood for many people world over, the global population is increasing tremendously and the targeted food production need to be increased before 2025 (Pennisi, 2008). Unsurprisingly, a large proportion of the two-thirds of the world's population that lack one or more essential mineral element in their diets rely on rice as their main staple. Phosphorus (P) is the most problematic nutrient in rice growing soils (Shen et al, 2011). In fact most of the rice growing soils lack the optimum levels of $\mathrm{P}$ for growth and development of rice (Fairhurst et al, 1999). Because of these reasons farmers tend to apply more $\mathrm{P}$ fertilizer, but consequently they pollute the environment and increase the cost of production. Governments of the developing countries including India spend lot of money on fertilizer imports. The situation is further aggravated when government funded fertilizer subsidies are placed due to numerous socio-economic and political reasons (Cordell et al, 2009). Organic rice growers also face difficulties as the popular organic manure such as crop stubbles and straw lack sufficient levels of P (Sirisena and Wanninayake 2014). Therefore, an alternative strategy to overcome the $P$ fertilizer led crisis is required. To solve this problem, the plant research community considers breeding of $\mathrm{P}$ deficiency (PD) tolerant rice varieties as the most promising solution (Rose et al, 2011). 
Recently quantitative genetic studies were begun to dissect the underlying genetics of PD tolerance in rice (Chin et al, 2011). A major quantitative trait locus (QTL) controlling PD tolerance was identified on the rice chromosome 12 using recombinant inbred lines (RILs) generated from a cross between a PD tolerant landrace Kasalath and sensitive landrace Nipponbare (Wissuwa et al, 2002). Later this QTL was fine mapped and labeled as Pupl (Chin et al, 2011). Markers associated to these QTL were points to the potential of identifying the lines PD tolerance information from same or different backgrounds. Moreover, this marker assisted selection (MAS) is rapidly increase the selection authenticity and efficiency PD tolerance lines.

There is growing recognition that improvements in internal $\mathrm{P}$ utilization efficiency are needed to complement enhanced $\mathrm{P}$ uptake traits if breeding $\mathrm{P}$ efficient crop cultivars has to be successful (Wang et al, 2010). Hence screening rice genotypes having good phosphorus use efficiency have to be explored and thus can be utilized in crop improvement programmes to improve yield and enhance food security in rice dependant countries. Therefore, the present study was conducted to characterize a set of local genotypes and landraces of rice cultivars evaluated for PD tolerance in field condition for phosphorus use efficiency using Pup1-K46 and Pup1-K52 marker locus to lay a foundation for MAB to produce better performing rice varieties under low $\mathrm{P}$ conditions.

\section{MATERIALS AND METHODS}

\section{Plant Materials}

A set of 120 rice cultivars (composed of upland cultivars and landraces) were obtained from Department of Plant Breeding and Genetics, Tamil Nadu Agricultural University (TNAU), Coimbatore, India which includes six genotypes of NILs (Near Isogenic Lines) developed from crossing the P-deficient tolerant traditional aus-type variety 'Kasalath' and the intolerant modern variety IR 74 and the other three genotypes were NILs developed by crossing Kasalath and the intolerant modern variety IR 64. These nine lines carried a chromosomal segment containing the putative quantitative trait locus (QTL) that had been transferred from the donor variety Kasalath, which acts as a positive control.

\section{Methods}

The field experiment with 120 genotypes was conducted in irrigated lowland with low phosphorus content at Agricultural Research Station, Bhavanisagar during 2014-15. Graded levels of P were added by adding single superphosphate at rates of 0,25 and $50 \mathrm{~kg} \mathrm{P}_{2} \mathrm{O}_{5} \mathrm{ha}^{-1}$. The genotypes were sown in nursery and after 23 DAS (days after sowing), the seedlings were transplanted in $1 \mathrm{~m}$ rows with 9 plants per row. The fertilizer was applied in three splits, basal, 15 DAT (days after transplanting) and 45 DAT. Phosphorus was applied in one dose as basal application to support early growth stage of the crop. Plants were grown under wetland conditions throughout the growth period. Available phosphorus content was determined by soil analysis at the time of planting. Composite soil samples were taken from 0-20 $\mathrm{cm}$ depth and analyzed for Bray $\mathrm{P}$ ( $\mathrm{pH}$ 5.8), which was found to be $9.2 \mathrm{~kg} \mathrm{ha}^{-1}$. The soil around the roots of each plant was loosened to a depth of 20-30 $\mathrm{cm}$ with a spade and the roots were slowly pulled out, which allowed most of the roots to be recovered from top soil. Roots were then washed and root length was measured. Roots, shoots and seeds were dried and weighed separately. The P content in roots, shoots and grains was determined calorimetrically by Vanadomolybdate yellow colour method (Piper, 1966).

\section{DATA COLLECTION}

After harvest, biometric traits observations viz, plant height $(\mathrm{cm})$, root length $(\mathrm{cm})$, number of tillers, 1000 grain 
weight $(\mathrm{g})$, grain yield $(\mathrm{kg})$, primary panicle length $(\mathrm{cm})$, primary panicle weight $(\mathrm{g})$ and biomass at vegetative and harvest stage were measured to evaluate the phosphorus use efficiency (PUE) of the genotypes under different treatments.

\section{DNA EXTRACTION AND PCR AMPLIFICATION}

Fresh rice leaves were collected from 20 days old seedlings and frozen in liquid nitrogen immediately, and stored at $-20^{\circ} \mathrm{C}$. Total genomic DNA was isolated using a modified cetyltrimethyl ammonium bromide (CTAB) method (Doyle, 1990). The quality and quantity of DNA were checked by agarose gel electrophoresis. The final concentration of all the samples was adjusted to $25 \mathrm{ng} \mu \mathrm{L}^{-1}$. The DNA templates from all the fifteen rice genotypes accessions were amplified using the Pup1 gene-specific primers namely Pup1-K46 and Pup1-K52 (Table.1). PCR amplification was performed in a Thermal Cycler (Eppendorf, Germany). A volume of $15 \mu \mathrm{L}$ of PCR mix contained $1.5 \mu \mathrm{L}$ of $10 \mathrm{X}$ assay buffer, $0.5 \mu \mathrm{L}$ of 2.5 Mm dNTPs, $0.20 \mu \mathrm{L}$ of 0.5 unit $\mu \mathrm{L}^{-1}$ of Taq polymerase $1.0 \mu \mathrm{L}$ of $10 \mu \mathrm{M}$ primer and $3.0 \mu \mathrm{L}$ of 25 ng $\mu \mathrm{L}^{-1}$ DNA. The temperature cycles were as follows: $4 \mathrm{~min}$ at $94^{\circ} \mathrm{C}$ followed by 35 cycles of $1 \mathrm{~min}$ at $94^{\circ} \mathrm{C}, 1 \mathrm{~min}$ at $57^{\circ} \mathrm{C}, 1 \mathrm{~min}$ extension at $72^{\circ} \mathrm{C}$. The final extension step was extended to $5 \mathrm{~min}$ at $72^{\circ} \mathrm{C}$ and finally maintained at $4{ }^{\circ} \mathrm{C}$. The amplified products were separated on a $3 \%$ agarose gel.

\section{DATA ANALYSIS}

The field collected data were subjected to single-environment ANOVAs to evaluate differences in yield characters and $\mathrm{P}$ concentration in grain and straw among genotypes within each environment and to calculate least square means for these variables in each environment using SAS software (SAS Institute Inc, 2012). The phosphorus use efficiency (PUE) of the rice genotypes grown under field condition was calculated as suggested by Syers et al. (2008).

\section{RESULTS AND DISCUSSIONS}

\section{Genotypic Variation for P Use Efficiency}

In case of screening of 120 genotypes, the range for each character under each individual treatment was given in Table 2. In case of plant height, IR 50 performed well under minus-P condition. CO 43 exhibited shorter stature under the treatment $25 \mathrm{~kg} \mathrm{ha}^{-1}$ of P and IR 74-Pup1-B had shorter height when $50 \mathrm{~kg} \mathrm{ha}^{-1}$ of $\mathrm{P}$ was applied. For the character number of tillers per plant, the variety Bharathi performed best at minus $\mathrm{P}$ conditions and Cult 1177 performed better when $\mathrm{P}$ was applied. CO 10 had significant total dry straw yield under minus-P condition. Cult 1177 had high dry straw yield under 25 $\mathrm{kg} \mathrm{ha}^{-1}$ of $\mathrm{P}$ applied condition, whereas ADT 44 performed well for total dry straw yield when $50 \mathrm{~kg} \mathrm{ha}^{-1}$ of $\mathrm{P}$ was applied. CO 45 exhibited significant primary panicle weight under minus-P condition. ASD 16 showed good primary panicle length and GEB 24 had significant single straw weight under minus-P condition. For the main economic trait grain yield, ASD 16 outweighed all the other 119 varieties under all the three treatments. For the character root length, which is a major trait for evaluating the $\mathrm{P}$ use efficiency, CO 46 performed well under minus-P conditions, with a root length of $26.9 \mathrm{~cm}$. The traditional landrace Kasalath and the NILs IR 74-Pup1-A, IR 64-Pup1-F, IR 74-Pup1-G, IR 74-Pup1-D, IR 74-Pup1-E and IR 64-Pup1-M with the Pup1 QTL exhibited root length of more than $20 \mathrm{~cm}$ which was more than that of most of the modern varieties. Another trait, root weight per plant indicates better P use efficiency of genotypes. And CO 44 and the NILs IR 74- Pup1-C, IR 74-Pup1-G and IR 74-Pup1-D performed well under minus P conditions.

\section{Genotypic Screening for Pup1 Marker}

Molecular markers are the popular approaches for discovering and tagging novel genes and alleles. These 
technologies can be effective in breeding programs through their use in Molecular Assisted Selection (MAS). MAS for PD-tolerance related QTLs under deficient has been effective in rice (Chin et al, 2010). The stability among various genotypes to select high yielding and PD tolerance rice lines is the key criterion for breeding programs. A high level of tolerance in rice genotypes against PD has been studied (Chin et al, 2010). But, identification and evaluation of rice tolerance lines against PD aiming at to combine phenotype screening linked with gene using PCR based markers is a better strategy in rice breeding.

Based on the grain yield character, fifteen genotypes (TKM 12, RMD 1, GEB 24, PMK 2, CO 34, ASD 16, IR 20, IR 72, IR 64, ADT 39, CO 46, TKM 3, TKM 6, TKM 9 and Kasalath) which possess highest grain yield among the 120 genotypes. These fifteen genotypes were selected and screened for probable presence of Pupl gene, which is the major PD tolerance gene in rice. Two Pupl gene linked markers Pup1-K46 and Pup1-K52 were used to test the genotypes by PCR amplification. The dominant marker Pup1-K46 produced the amplicon size of 523 bp in fourteen genotypes (Figure.1) and similarly Pup1-K52 dominant marker also produced the expected amplicon size of 505 bp in all the genotypes except IR 72 (Figure. 2). The gene-based Pupl markers that are now available have been extensively tested and provide sufficient details on the different Pupl haplotypes present in the rice genotypes. These results are in accordance with the reports of Heuer et al, (2009) and Tyagi et al, (2012).

Table 1: List of Markers Used to Screen Presence of Pup1 QTL

\begin{tabular}{|l|l|c|c|c|}
\hline $\begin{array}{c}\text { Marker } \\
\text { Name }\end{array}$ & \multicolumn{1}{|c|}{ Sequence } & Gradient Range (0 C) & $\begin{array}{c}\text { Annealing } \\
\text { Temp (o C) }\end{array}$ & $\begin{array}{c}\text { Kasalath } \\
\text { Allele (bp) }\end{array}$ \\
\hline $\begin{array}{l}\text { Pup1- } \\
\text { K46 }\end{array}$ & $\begin{array}{l}\text { 5'-TGAGATAGCCGTCAAGATGCT-3' (F) } \\
\text { 5'-AAGGACCACCATTCCATAGC-3' (R) }\end{array}$ & $54-59$ & 59 & 523 \\
\hline $\begin{array}{l}\text { Pup1- } \\
\text { K52 }\end{array}$ & 5'ACCGTTCCCAACAGATTCCAT-3' (F) & $54-59$ & 59 & 505 \\
\hline
\end{tabular}

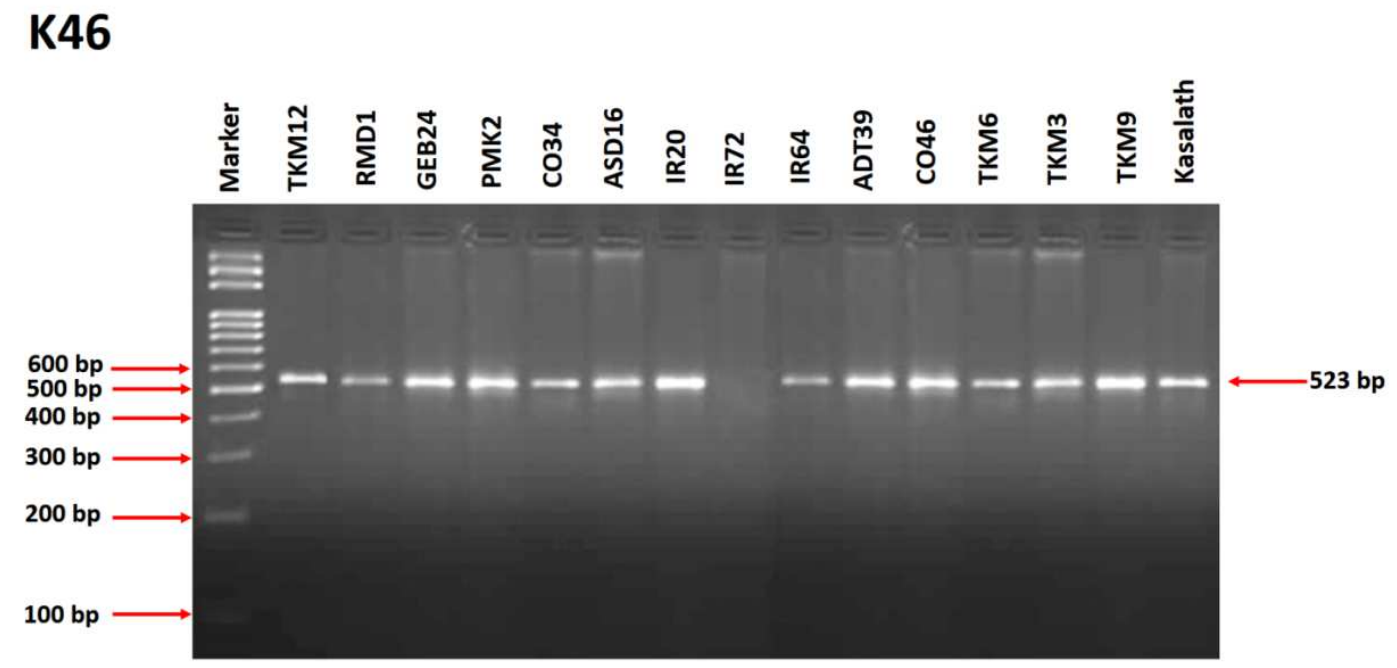

Figure 1: Amplicons Obtained with Pup1-K46 


\section{K52}

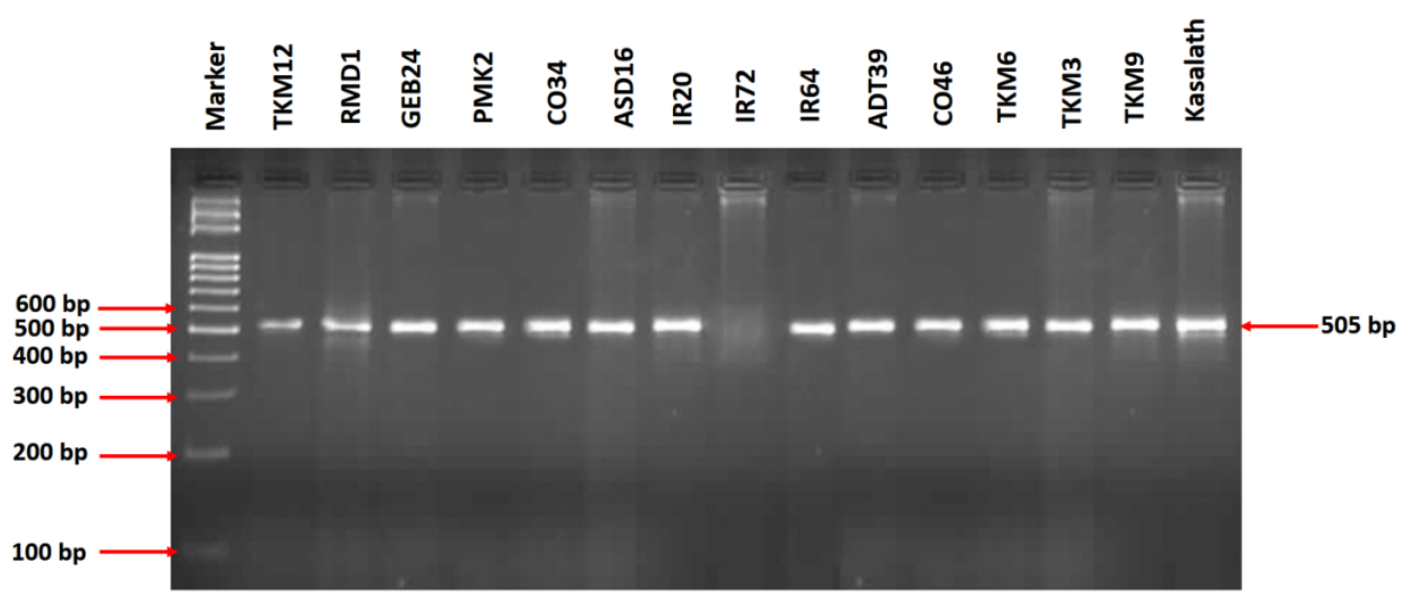

Figure 2: Amplicons Obtained with Pup1-K52

Table 2: Comparison of Grand Means of 120 Rice Genotypes

Grown at Three Levels of Pat Harvest Stage

\begin{tabular}{|c|c|c|c|c|c|c|}
\hline \multirow[t]{2}{*}{ Characters } & \multicolumn{3}{|c|}{ Range $\left(\mathrm{kg} \mathrm{ha}^{-1}\right)$} & \multicolumn{3}{|c|}{ Grand Mean $\left(\mathrm{kg} \mathrm{ha}^{-1}\right)$} \\
\hline & P0 & P25 & P50 & P0 & P25 & P50 \\
\hline Plant Height $(\mathrm{cm})$ & $72.4-141.3$ & $64.7-142.1$ & $69.5-143.7$ & 94.5 & 97.3 & 99.0 \\
\hline Root Length cm) & $8.0-26.9$ & $8.0-24.8$ & $9.1-24.2$ & 17.9 & 16.9 & 16.7 \\
\hline No. of tillers & $16.7-47.7$ & $17.3-40.3$ & $17.3-44.0$ & 29.9 & 27.3 & 28.6 \\
\hline $\begin{array}{l}\text { Straw Yield } \\
\left(\mathrm{kg} \mathrm{ha}^{-1}\right)\end{array}$ & $0.4-2.6$ & $0.4-2.5$ & $0.5-2.5$ & 1.1 & 1.1 & 1.1 \\
\hline $\begin{array}{l}1000 \text { Grain } \\
\text { Weight (g) }\end{array}$ & $12.2-32.7$ & $13.2-27.9$ & $12.9-32.3$ & 21.7 & 21.8 & 22.5 \\
\hline $\begin{array}{l}\text { Grain Yield } \\
\left(\mathrm{kg} \mathrm{ha}^{-1}\right)\end{array}$ & $0.11-0.5$ & $0.09-0.51$ & $0.12-0.5$ & 0.3 & 0.3 & 0.3 \\
\hline $\begin{array}{l}\text { Primary Panicle } \\
\text { Weight }(\mathrm{g})\end{array}$ & $0.9-4.0$ & $0.9-4.1$ & -4.0 & 2.4 & 2.2 & 2.1 \\
\hline $\begin{array}{l}\text { Primary Panicle } \\
\text { Length }(\mathrm{cm})\end{array}$ & $20.2-33.9$ & $18.5-33.8$ & $19.0-34.9$ & 25.2 & 24.7 & 25.7 \\
\hline 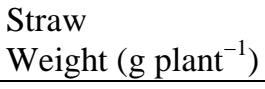 & $12.8-54.0$ & $13.5-52.7$ & $16.8-57.7$ & 31.5 & 29.7 & 31.9 \\
\hline 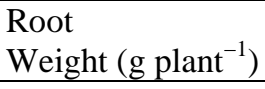 & $13.3-45.3$ & $13.0-47.8$ & $11.3-46.8$ & 23.3 & 23.3 & 23.3 \\
\hline PUE (\%) & & $39.8-192.6$ & $29.5-108.1$ & 107.7 & 103.2 & $\begin{array}{c}105 . \\
4\end{array}$ \\
\hline
\end{tabular}

\section{CONCLUSIONS}

In this study, fourteen genotypes were identified as PD tolerant genotypes, which could provide an elite array of tolerance source for effective breeding of rice cultivars to PD. Based on PUE (\%) cultivars like PMK 2, CO 46, TKM 3, GEB 24, IR 20 and TKM 6 were found to be phosphorus deficient tolerant rice genotypes. It is also confirmed that these genotypes may possess pup1 gene as evident from the PUE (\%) calculated based on low phosphorus soil screening. Further studies are required to validate the presence of pup1 gene by sequencing technologies. In addition, many P-deficient soils are constrained by other stresses like aluminium toxicity, salinity, and nematodes etc that restrict root growth and interfere 
with Pup1 phenotyping. It is concluded that those genotypes may serve as phosphorus tolerant genotypes in future breeding programs and genetic studies on phosphorus deficiency tolerance to detect potentially novel genetic mechanisms.

\section{REFERENCES}

1. Chin, J.H, Gamuyao, R, Dalid, C, Bustamam, M, Prasetiyono, J, Moeljopawiro, S, Wissuwa, M. and Heuer, S. (2011). Developing rice with high yield under phosphorus deficiency: Pup1 sequence to application. Plant Physioliology 156: 12021216.

2. Chin, J.H, Lu, X, Haefele, H.M, Gamuyao, R, Ismail, A.M, Heuer, S. and Wissuwa, M. (2010). Development and application of gene-based markers for the major rice QTL Phosphorus uptake 1. Theoretical and Applied Genetics 120: 1073-1086.

3. Cordell, D, Drangert, J.O. and White, S. (2009). The story of phosphorus: global food security and food for thought. Global Environmental Change 19: 292-305.

4. Fairhust, T, Lefroy, R, Mutert, E. and Batjes, N.H. (1999). The importance, distribution and causes of phosphorus deficiency as a constraint to crop production in the tropics. Agroforestry Forum 9: 2-9.

5. Heuer, S, Lu, X, Chin, J.H, Tanaka, J.P, Kanamori, H, Matsumoto, T, De Leon, T, Ulat, V.J, Ismail, A.M, Yano, M. and Wissuwa, M. (2009). Comparative sequence analyses of the major quantitative trait locus Phosphorus uptake 1 (Pup1) reveal a complex genetic structure. Plant Biotechnology Journal 7 (5): 456-471.

6. Pennisi E 2008. The Blue Revolution, drop by drop, gene by gene. Science 320:171-173.

7. Rose, T.J, Rose, M.T, Pariasca-Tanaka, J, Heuer, S. and Wissuwa, M. (2011). The frustration with utilization: Why have improvements in internal phosphorus utilization efficiency in crops remained so elusive?. Frontiers in Plant Science 73 (2): 15 .

8. SAS Institute Inc.(2012). SAS/STAT9.3 User's Guide, 2ndEdn. Cary, NC:SAS Institute Inc.

9. Shen, J, Yuan, L, Zhang, J, Li, H, Bai, Z, Chen, X, Zhang, W. and Zhang, F. (2011). Phosphorus dynamics: From soil to plant. Plant Physiology 156: 997-1005.

10. Sirisena, D.N. and Wanninayake, W.M.N. (2014). Identification of promising rice varieties for low fertile soils in the low country intermediate zone in Sri Lanka. Annals of Sri Lanka Department of Agriculture 16: 95-105.

11. Syers JK, Johnston AE, Curtin D (2008) Efficiency of soil and fertilizer phosphorus use. Reconciling changing concepts of soil phosphorus behavior with agronomic information. FAO Fertil Plant Nutr Bull 18:108.

12. Tyagi W, Rai M and Dohling A (2012). Haplotype analysis for locus in rice genotypes of north eastern and eastern india to indetify suitable donors tolerant to low phosphorus. Journal of Breeding and Gentics 44(2): 398-405.

13. Wang, X, Shen, J, and Liao, H. (2010). Acquisition or utilization, which is more critical for enhancing phosphorus efficiency in modern crops? Plant Sci. 179, 302-306.

14. Wissuwa M, Wegner J, Ae N, Yano M (2002) Substitution mapping of Pup1: a major QTL increasing phosphorus uptake of rice from a phosphorus deficient soil. Theor Appl Genet 105: 890-897. 